Opondo, D., Visscher, S., Eslami, S., Medlock, S., Verheij, R., Korevaar, J.C., Abu-Hanna, A. Feasibility of automatic evaluation of clinical rules in general practice. International Journal of Medical Informatics: 2017, 100(4), 90-94

\begin{tabular}{|l|l|}
$\begin{array}{l}\text { Postprint } \\
\text { Version }\end{array}$ & 1.0 \\
\hline Journal website & http://www.ijmijournal.com/article/S1386-5056(17)30010-2/fulltext \\
\hline Pubmed link & $\underline{\text { https://www.ncbi.nlm.nih.gov/pubmed/28241942 }}$ \\
\hline DOI & 10.1016/j.jjmedinf.2017.01.010
\end{tabular}

This is a NIVEL certified Post Print, more info at http://www.nivel.eu

\title{
Feasibility of automatic evaluation of clinical rules in general practice
}

\author{
DEDAN OPONDO $^{\mathrm{A},}$, STEFAN VISSCHER $^{\mathrm{B}}$, SAIED ESLAMI ${ }^{\mathrm{A}, \mathrm{C}}$, STEPHANIE MEDLOCK $^{\mathrm{A}}$, ROBERT \\ VERHEIJ $^{\mathrm{B}}$, JOKE C. KOREVAAR ${ }^{\mathrm{B}}$, AMEEN ABU-HANNA $^{\mathrm{A}}$ \\ ${ }^{a}$ Department of Medical Informatics, Academic Medical Center, Meibergdreef 15, 1105 AZ \\ Amsterdam, The Netherlands \\ ${ }^{\mathrm{b}}$ Netherlands Institute for Health Services Research (NIVEL), PO BOX 1568, 3500 BN \\ Utrecht, The Netherlands \\ ${ }^{c}$ Pharmaceutical Research Center, School of Pharmacy, Mashhad University of Medical \\ Sciences, Mashhad, Irana
}

\section{HighLIGHTS}

- $40 \%$ of ACOVE indicators can be automatically evaluated in Dutch general practice.

- Sub-optimal statement of indicators impedes automatic evaluation of healthcare.

- Modification of GP databases is required to optimize evaluation of healthcare.

- LERM is feasible method for analyzing clinical rules in quality evaluation.

\begin{abstract}
Purpose: To assess the extent to which clinical rules (CRs) can be implemented for automatic evaluation of quality of care in general practice.

Methods: We assessed 81 clinical rules (CRs) adapted from a subset of Assessing Care of Vulnerable Elders (ACOVE) clinical rules, against Dutch College of General Practitioners (NHG) data model. Each CR was analyzed using the Logical Elements Rule

Method: (LERM). LERM is a stepwise method of assessing and formalizing clinical rules for decision support. Clinical rules that satisfied the criteria outlined in the LERM method were judged to be implementable in automatic evaluation in general practice.

Results: Thirty-three out of 81 (40.7\%) Dutch-translated ACOVE clinical rules can be automatically evaluated in electronic medical record systems. Seven out of 7 CRs (100\%) in the domain of diabetes can be automatically evaluated, 9/17 $(52.9 \%)$ in medication use, $5 / 10(50 \%)$ in depression care, $3 / 6(50 \%)$ in nutrition care, 6/13 (46.1\%) in dementia care, $1 / 6(16.6 \%)$ in end of life care, 2/13 $(15.3 \%)$ in continuity of care, and $0 / 9(0 \%)$ in the fall-related care. Lack of
\end{abstract}


Opondo, D., Visscher, S., Eslami, S., Medlock, S., Verheij, R., Korevaar, J.C., Abu-Hanna, A. Feasibility of automatic evaluation of clinical rules in general practice. International Journal of Medical Informatics: 2017, 100(4), 90-94

documentation of care activities between primary and secondary health facilities and ambiguous formulation of clinical rules were the main reasons for the inability to automate the clinical rules.

Conclusion: Approximately two-fifths of the primary care Dutch ACOVE-based clinical rules can be automatically evaluated. Clear definition of clinical rules, improved GP database design and electronic linkage of primary and secondary healthcare facilities can improve prospects of automatic assessment of quality of care. These findings are relevant especially because the Netherlands has very high automation of primary care.

\section{INTRODUCTION}

Quantification of quality of care is critical for quality management in general practice. Specifically, measurement of quality of care allows general practitioners to appraise the current status of quality and to identify opportunities for improvement. Evaluation of quality of care utilizes predefined sets of clinical rules against which data collected from electronic medical record (EMR) are evaluated [1]. These evaluation activities are often performed retrospectively. This approach is tedious, time consuming and presents performance results months after the target clinical process activities have occurred. Opportunities for timely intervention are thus lost. Increasing demand for adherence to several clinical guidelines and clinical rules make it even more difficult to perform quality of care assessment manually. Moreover, large amounts of data that are generated in contemporary general practice make analysis of quality of care cumbersome and labor intensive. Automatic evaluation of care can be used to solve the problem of large data in general practices. Automation is important because it allows for applications such as quality assessment and real time decision support. Automation provides timely feedback to general practitioners that enable them to change their practice and thus improve quality of care.

Automatic evaluation of quality of care requires compatibility of clinical rules and clinical databases in terms of definition of concepts. Unfortunately, most clinical rules are formulated in natural language without considering that they can be represented in a computer interpretable format.

In this study, we investigated the extent to which the quality of care provided to elderly persons can be automatically evaluated using EMR data that is routinely recorded by general practices in the Netherlands. We use clinical rules adapted from the Assessing Care of Vulnerable Elders (ACOVE) clinical rules to evaluate the feasibility of automatic evaluation of quality of care of elderly persons at the general practice level [2].

\section{METHODS}

\subsection{ACOVE clinical rules}

ACOVE clinical rules were developed by the RAND corporation in the USA to assess quality of care of elderly persons [2]. A subset containing 81 clinical rules (CRs) were translated for evaluating quality of care in general practice by a panel of Dutch geriatric care experts [3]. In this translation, the Dutch experts selected only 
Opondo, D., Visscher, S., Eslami, S., Medlock, S., Verheij, R., Korevaar, J.C., Abu-Hanna, A. Feasibility of automatic evaluation of clinical rules in general practice. International Journal of Medical Informatics: 2017, 100(4), 90-94

ACOVE clinical rules relevant to general practice. The CRs are divided into eight domains of care namely: organization of continuity of care, dementia care, depression care, diabetes care, end of life care, prevention and management of falls, appropriate medication use and, diagnosis and management of under nutrition. The CRs are formulated as IF ....THEN statements. A given clinical condition or state in the IF segment of the CR prompts an action in the THEN segment of the CR. An example of the CRs reads as follows: IF a vulnerable elder has diabetes, THEN glycated hemoglobin should be measured at least annually.

\subsection{Data source}

General practitioners (GPs) in the Netherlands universally use electronic medical records (EMR) to document patient information.

\subsection{Description of standard reference model of EMRs in dutch general practice}

The Dutch College of General Practitioners publishes a reference model which describes a minimum dataset that all EMRs in Dutch general practice must collect. EMRs databases are derived from the same reference model to facilitate data exchange and aggregation. In this study, we used the NHG database model to establish the data variables that are collected from the EMR databases.

Patient contacts are classified as consultations, home visits or drug prescriptions. General practitioners link each contact to specific clinical episodes of care. An episode is defined as a medical problem for which a patient seeks medical assistance, for example hypertension or diabetes. Patient diagnosis (es) in each contact is coded using the International Classification for Primary Care (ICPC) [4].

Patient characteristics in the EMR databases include age and gender.

Data collected about the general practices include; type of practice, geographical location and urbanization level of the locality of the practice. The brand of EMR used in each practice is also documented. Findings of diagnostic procedures such as physical examination, specific elements of history, functional tests, imaging examinations and laboratory tests are coded and documented using a terminology developed by the Dutch College of General Practitioners (NHG).

The EMR databases also contain prescription data. Each prescription is a single record. Details about each prescription include date and time, code name of drug, amount and frequency. The anatomical and therapeutic chemical (ATC) classification system is used for the coding the name of the medication [5].

\subsection{LERM analysis}

We analyzed 81 clinical rules using the Logical Elements Rule Method (see supplementary table for a list of the CRs). LERM analyzes a clinical rule to establish if the terms and concepts that constitute it can be represented in a computer interpretable form [6] ; [7]. Each CR was analyzed separately. Fig. 1 illustrates the steps in the analysis of the CR.

<img class="figure large" border="0" alt="Fig. 1" src="http://origin-ars.elscdn.com.proxy.library.uu.nl/content/image/1-s2.0-S1386505617300102-gr1.jpg" data-thumbEID="1-s2.0-S1386505617300102-gr1.sml" data-imgEIDs="1-s2.0S1386505617300102-gr1.jpg" data-fullEID="1-s2.0-S1386505617300102-gr1.jpg"> Fig. 1.

An illustration of the steps in the LERM analysis of a sample clinical rule. 
Opondo, D., Visscher, S., Eslami, S., Medlock, S., Verheij, R., Korevaar, J.C., Abu-Hanna, A. Feasibility of automatic evaluation of clinical rules in general practice. International Journal of Medical Informatics: 2017, 100(4), 90-94

\section{[FIGURE1]}

The first step involved analyzing whether the CR could be proactively operationalized. A proactively stated CR is one which can be used to make a decision for a clinical intervention when its condition is fulfilled. A non-proactive CR is one whose condition and recommendation is temporally invalid. Non proactive CR do not give the physician any opportunity to change practice because it is aimed at foregone events. For example: IF a vulnerable elder who had dyspnea in the last 7 days of life died an expected death, THEN the general practitioners record should document a dyspnea management plan. In this clinical rule, no intervention can be implemented because the patient has already died. Non-proactive CRs are thus limited to assessing past performance. The sample CR about diabetes is proactive, because the GP has an opportunity to test the patient when the condition is met. Secondly, each CR was formulated into a logical statement. During this process phrases containing concepts were extracted from the statement of the indicator. In the illustration, the following concepts phrases were extracted from the logical statement: Vulnerable elder, diabetes mellitus, glycated hemoglobin(HBA1c) and date of last laboratory test.

Thirdly, concepts extracted from the clinical rule are converted to data variables, as they would be represented in EMR databases. We then assess if all data variables that constitute each clinical rule are documented in the EMR databases in a sufficient detail to allow for development of electronic feedback to the general practitioners. Clinical rules whose data variables are captured in the EMR database were considered to be amenable for automatic evaluation at the point of care. These steps were repeated for each of the 81 clinical rules.

\section{RESULTS}

Table 1 shows clinical rules which can be used for automatic assessment of quality of care. Overall 33 out of 81 clinical rules were found to be evaluable with the current data available in the EMR databases. The following paragraphs explain the results of the analysis for each domain of care.

\section{[TABLE 1]}

\subsection{Continuity of care}

Two of thirteen clinical rules associated with continuity of care were found to be amenable for automation. The two clinical rules involve the follow up of diagnostic laboratory results and scheduled preventive care such as vaccinations. Three CRs were found to be ambiguous in their definitions. These CRs would be evaluable if they were redefined. Four CRs that involve documentation of information that is generated at hospital discharge and two CRs that involve information sharing between the nursing home and GP practice could not be automated since there was no electronic data linkage between nursing homes and GP practices. Two CRs regarding information sharing when a patient migrates from one GP practice to another or when a patient receives medication from another GP practice to was not automatable. There existed no electronic linkage between GP practices at the time of this analysis. 
Opondo, D., Visscher, S., Eslami, S., Medlock, S., Verheij, R., Korevaar, J.C., Abu-Hanna, A. Feasibility of automatic evaluation of clinical rules in general practice. International Journal of Medical Informatics: 2017, 100(4), 90-94

\subsection{Depression care}

Five out of ten CRs in the domain of depression care could be automated. Three of the six CRs involve documentation of co morbidities at the time of diagnosis of dementia. Two deal with prescription of treatment for depressed patients. On the contrary, one CR that deals with providing patient information is not evaluable since the patient information is not documented. Similarly, two CRs regarding assessment of response to treatment and judgment of suicidal ideation by a depressed patient could not be automated since responses to treatment were not documented in this database.

\subsection{Dementia care}

Six out of thirteen CRs about dementia care could be automated. Five of the six deal with documentation required at the time of diagnosis of dementia such as cognitive function, use of medication and laboratory investigations. Five CRs were not sufficiently defined to allow for the mapping of their data concepts. Two are however well defined but could not be automated because their data concepts were not captured in the EMR databases.

\subsection{Diabetes care}

All seven CRs associated with diabetes could be automated. They involve schedules of follow up laboratory examination or indication for initiating additional treatment for diabetic patients.

\subsection{Medication use}

Nine out of seventeen CRs associated with medication use could be automated. Three CRs involve regular review of the current and previous medications that the patient has been taking. Another three (3) CRs deal with laboratory follows up of patients on medication. One CR deals with co-prescription of gastroprotective medication with NSAIDs. Two CRs involve duration of treatment with benzodiazepines and prescription of alternative medication to strong anticholinergic medications. Seven clinical rules could not be automated because their data elements are not captured by the NHG data model. The CRs deal with patient counselling about medication use and justification of specific medication use. One clinical rule required data from both the GP EMR and Dutch Thrombosis Service. Such data was not contemplated in the NHG datamodel.

\subsection{Nutritional care}

Three out of six CRs associated with nutritional care could be automated. One CR involves prescription of Vitamin D use to the elderly. Two CRs deal with diagnosis of nutritional disorders by monitoring weight of the patient and documenting causes of weight loss and documenting weight of patients suffering from chronic obstructive airway disease. A CR regarding referral of patients with decubitus to a dietitian cannot be automated.

\subsection{Falls and morbidity}

None of the nine CRs in the domain of prevention of fall can be automated. There is no standardized coding for falls in the terminology systems that were used in the GP practice, and were therefore not available in the EMR databases. 
Opondo, D., Visscher, S., Eslami, S., Medlock, S., Verheij, R., Korevaar, J.C., Abu-Hanna, A. Feasibility of automatic evaluation of clinical rules in general practice. International Journal of Medical Informatics: 2017, 100(4), 90-94

\subsection{End of life care}

One out of six CRs associated with end of life care can be automated. The CR concerns prescription of opioid analgesic to patients with metastatic cancer or terminal pulmonary disease. Four of the CRs are not proactive because that they are meant to review the quality of palliative care provided around the time death. They can only be evaluated in retrospect, postmortem. One CR was insufficiently defined to allow for assessment using currently available data.

\section{DISCUSSION}

\subsection{Main findings}

Thirty three $(40.7 \%)$ out of eighty one Dutch translated ACOVE clinical rules can be automatically evaluated based on the current data collected by the Dutch general practices. Majority of clinical processes that can be automatically evaluated deal with specific well coded diagnosis such as diabetes or depression and medication use. However, the number of CRs regarding continuity of care that can be automatically evaluated is low. This is mainly because information sharing between hospitals, nursing homes, and general practices is mainly not electronic. Clinical letters and other paper-based media are used between GP practices and other health service providers. These materials contain unstructured clinical information and are not stored in the EMR databases. Flink et al. have previous highlighted the lack of patient-centered documentation between hospitals and primary health care and how impairs continuity of care [8].

Moreover, CRs that were less specifically defined were found to be inappropriate for automatic evaluation. Lack of detail in the formulation of clinical rules offsets the ability to evaluate them effectively [9]. Use of implementability appraisal frameworks by authors of clinical rules may reduce ambiguity and improve their implementation and subsequent evaluation [10]. Likewise, future revisions of CRs may consider redefinition of concepts to make them more specific. Two approaches are therefore necessary to increase the ability of clnical rules to be automatically assessed using existing clinical data. The first is to try and re-formulate the concepts in the clinical rules clearly to allow for easy mapping to the target source of clinical data [11]. This can be done by using guideline representation languages [12]. Secondly, standardization of documentation is necessary to improve data sharing between general practices, nursing homes and hospitals. Standardization potentially improves the quality of data generated from transmural care activities.

Our study demonstrates the potential of the EMRs in automated monitoring of quality of care in general practice. Automation provides an opportunity for timely feedback to the general practitioners. Prompt feedback can be in the form of realtime measurement of clinical rules. The GP compares his/her performance against quality benchmarks. Alternatively, automation can be implemented in the form of real time clinical decision support, for example in the form of alerts or reminders, available at the point of care.

Quality evaluation research in such a case is a secondary application for the clinical data [13]. Re-use of clinical databases is widely accepted in several research domains such as clinical epidemiology and decision analysis among others [14]. Re-use is often motivated by the fact that primary data collection for quality assurance is expensive [15]. Re-use of data nevertheless has its weaknesses such as incomplete 
Opondo, D., Visscher, S., Eslami, S., Medlock, S., Verheij, R., Korevaar, J.C., Abu-Hanna, A. Feasibility of automatic evaluation of clinical rules in general practice. International Journal of Medical Informatics: 2017, 100(4), 90-94

data, inappropriate terminology for the secondary application and undocumented observations.

We used a structured method that not only examines the data source model but also examines the inherent features of a clinical rule that determine if it can be electronically evaluated. The benefit of this approach is the ability to identify CRs that can be transmuted into clinical rules for clinical decision support. By selecting CRs that can be automatically assessed one is able to measure the level of performance and simultaneous implement decision support. Automated monitoring of quality of cares supports the dual goals of measurement as well as improving care. Interventions can be instituted promptly in cases where the quality of care is suboptimal.

\subsection{Future studies}

Our study analyzed the possibility of automatic evaluation quality of care-based data collected by EMRs at GP practices. Individual studies involving each of the CRs can be performed to evaluate the impact of automatic assessment of quality of care on patient's outcomes in general practice. Furthermore it is possible to conduct studies on clinical decision support based on the clinical rule identified in this study. Such studies would give more insight on how quality the twin aspects of quality measurement and improvement can be simultaneously implemented.

\section{CONCLUSION}

Approximately two-fifths of the ACOVE based clinical rules relevant for general practice can be automatically evaluated. Clear definition of clinical rules, improved GP database design and electronic linkage of transmural care activities can improve prospects of automatic assessment of quality of care.

\section{AUTHORS' CONTRIBUTIONS}

DO and SE were involved in the design and implementation of the study.

DO and SV performed analysis of the clinical rules.

SE, SV, SM, JK, RV and AA critically revised the manuscript.

All authors read and approved the final version of the manuscript.

\section{CONFLICT OF INTEREST}

The authors declare that they have no conflict of interest related to this work.

\section{SUMMARY POINTS}

What was already known on the topic:

- Clinical guidelines when implemented in electronic medical records systems improve quality of care

What this study adds to our knowledge:

- Automatic evaluation of quality of care can be implemented in general practice using clinical rules.

- Optimal statement of clinical rules and clinical guidelines is required to support automated evaluation of quality of care.

- Modification of databases used in general practices may be required to enable automatic evaluation of quality of care. 
Opondo, D., Visscher, S., Eslami, S., Medlock, S., Verheij, R., Korevaar, J.C., Abu-Hanna, A. Feasibility of automatic evaluation of clinical rules in general practice. International Journal of Medical Informatics: 2017, 100(4), 90-94

- The LERM is a practical and feasible method for analyzing the implementability of clinical rules in computerized quality evaluation.

\section{ACKNOWLEDGMENTS}

This work was supported by ZonMw (The Netherlands Organization for Health Research and Development) by a grant to the ICOVE project (\#311020302). The funder had no role in study design, data collection and analysis, decision to publish, or preparation of the manuscript.

\section{APPENDIX A. SUPPLEMENTARY DATA}

\section{REFERENCES}

[1] H.H.S. Campbell Quality Indicators for General Practice A Practical Guide for Health Professionals and Managers Royal Society of Medicine Press (2002)

[2] P.G. Shekelle, C.H. MacLean, S.C. Morton, N.S. Wenger Assessing care of vulnerable elders: methods for developing quality indicators Ann. Intern. Med., 135 (2001), pp. 647652

[3] E. van der Ploeg, M.F. Depla, P. Shekelle, H. Rigter, J.P. Mackenbach Developing quality indicators for general practice care for vulnerable elders; transfer from US to The Netherlands Qual. Saf. Health Care, 17 (2008), pp. 291-295

[4] M. Verbeke, D. Schrans, S. Deroose, J. De Maeseneer The international classification of primary care (ICPC-2): an essential tool in the EPR of the GP Stud. Health Technol. Inform., 124 (2006), pp. 809-814

[5] W.C.C.f.D.S Guidelines for ATC Classification and DDD Assignment WHO (2011)

[6] S. Medlock, S. Eslami, D. Opondo, M. Askari, S. De Rooij, A. Abu-Hanna Application of the logical elements rule method for formalization of clinical rules: case study of ACOVENLI Stud. Health Technol. Inform., 180 (2012), pp. 421-426

[7] S. Medlock, D. Opondo, S. Eslami, M. Askari, P. Wierenga, S.E. de Rooij, A. Abu-Hanna LERM (Logical Elements Rule Method): a method for assessing and formalizing clinical rules for decision support Int. J. Med. Inform., 80 (2011), pp. 286-295

[8] M. Flink, S. Bergenbrant Glas, F. Airosa, G. Ohlen, P. Barach, H. Hansagi, M. Brommels, $M$. Olsson Patient-centered handovers between hospital and primary health care: an assessment of medical records Int. J. Med. Inform., 84 (2015), pp. 355-362

[9] A.R. Gagliardi, M.C. Brouwers Integrating guideline development and implementation: analysis of guideline development manual instructions for generating implementation advice Implement. Sci., 7 (2012), p. 67

[10] R.N. Shiffman, J. Dixon, C. Brandt, A. Essaihi, A. Hsiao, G. Michel R. O'Connell The GuideLine Implementability Appraisal (GLIA): development of an instrument to identify obstacles to guideline implementation BMC Med. Inform. Decis. Mak., 5 (2005), p. 23

[11] M. Peleg, S.W. Tu Design patterns for clinical guidelines Artif. Intell. Med., 47 (2009), pp. $1-24$

[12] P.A. de Clercq, J.A. Blom, H.H. Korsten, A. Hasman Approaches for creating computerinterpretable guidelines that facilitate decision support Artif. Intell. Med., 31 (2004), pp. 127

[13] W.M. Tierney, C.J. McDonald Practice databases and their uses in clinical research Stat. Med., 10 (1991), pp. 541-557

[14] M.G. Weiner, P.J. Embi Toward reuse of clinical data for research and quality improvement: the end of the beginning? Ann. Intern. Med., 151 (2009), pp. 359-360

[15] F. Kopcke, S. Kraus, A. Scholler, C. Nau, J. Schuttler, H.U. Prokosch, T. Ganslandt Secondary use of routinely collected patient data in a clinical trial: an evaluation of the effects on patient recruitment and data acquisition Int. J. Med. Inform., 82 (2013), pp. 185192 
Opondo, D., Visscher, S., Eslami, S., Medlock, S., Verheij, R., Korevaar, J.C., Abu-Hanna, A. Feasibility of automatic evaluation of clinical rules in general practice. International Journal of Medical Informatics: 2017, 100(4), 90-94

\section{FIGURES AND TABLES}
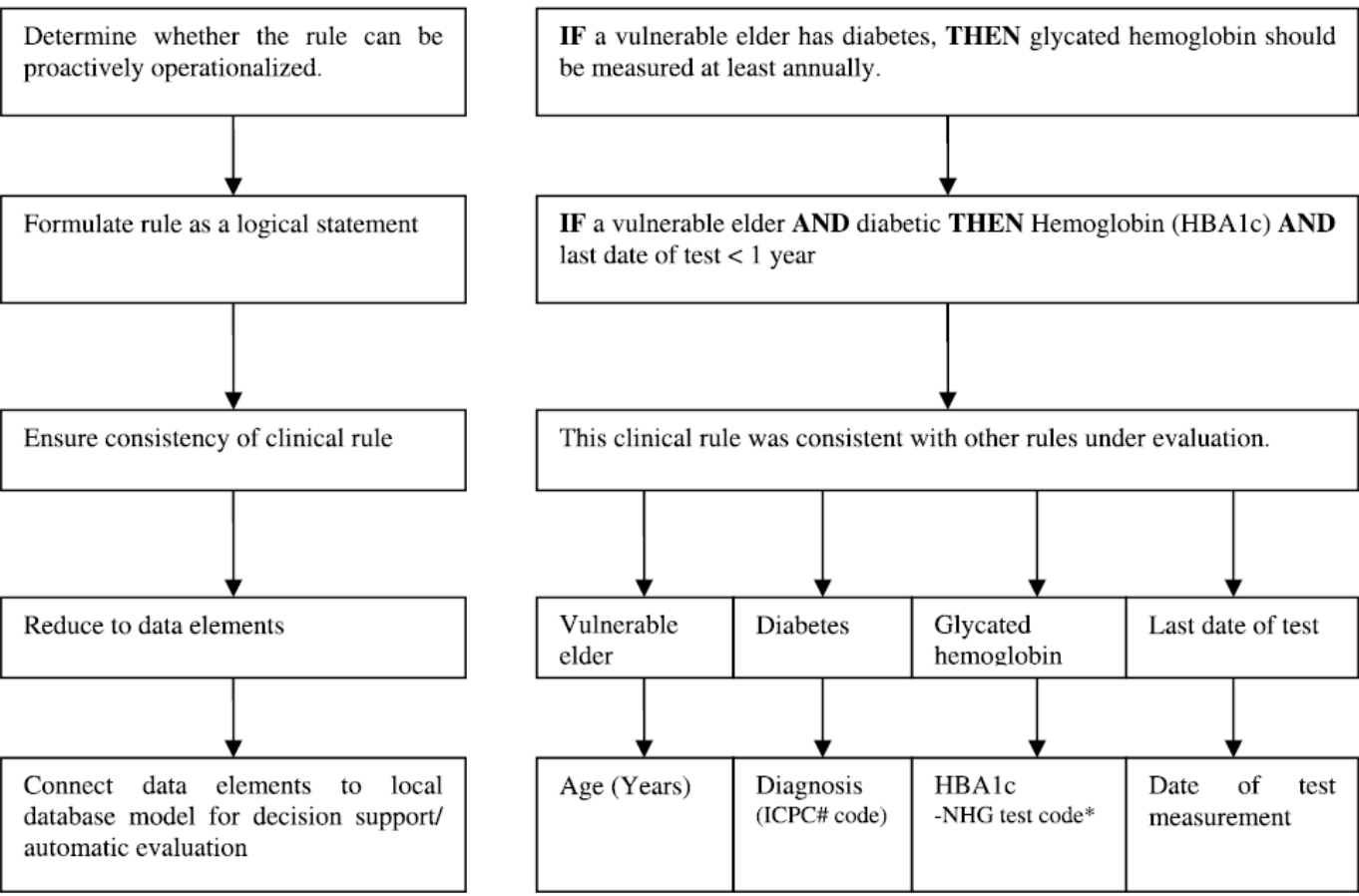

Fig. 1. An illustration of the steps in the LERM analysis of a sample clinical rule.

Table 1. : Number of ACOVE based clinical rules that can be evaluated in Dutch General Practice per domain of care.

\begin{tabular}{|c|c|c|c|c|}
\hline \begin{tabular}{|l} 
ACOVE \\
Domain of \\
care \\
\end{tabular} & \begin{tabular}{|l} 
No of \\
clinical \\
rules $(\mathrm{n})$ \\
\end{tabular} & \begin{tabular}{|l} 
Proactive \\
Clinical rules \\
(n)
\end{tabular} & \begin{tabular}{|l} 
Clinical rules \\
reducible to data \\
elements $(\mathrm{n})$ \\
\end{tabular} & \begin{tabular}{|l} 
Clinical rules with \\
data in GP \\
database $(n)$ \\
\end{tabular} \\
\hline $\begin{array}{l}\text { Continuity of } \\
\text { care }\end{array}$ & 13 & 13 & 4 & 2 \\
\hline Depression & 10 & 10 & 8 & 5 \\
\hline Dementia & 13 & 13 & 8 & 6 \\
\hline Diabetes & 7 & 7 & 7 & 7 \\
\hline Medication use & 17 & 16 & 9 & 9 \\
\hline Nutrition care & 6 & 6 & 4 & 3 \\
\hline $\begin{array}{l}\text { Falls and } \\
\text { mobility care }\end{array}$ & 9 & $\| 9$ & 8 & 0 \\
\hline End of life care & 6 & 3 & 2 & 1 \\
\hline TOTAL & 81 & 77 (95.0\%) & $50(61.7 \%)$ & $33(40.7 \%)$ \\
\hline
\end{tabular}

\section{APPENDIX}




\section{List of quality indicators derived from the Assessing Care of Vulnerable Elders Study (ACOVE)}

\begin{tabular}{|c|c|}
\hline & Quality Indicators \\
\hline $\begin{array}{l}\text { Ref } \\
\text { No. }\end{array}$ & Continuity and Coordination of Care \\
\hline 1 & $\begin{array}{l}\text { IF a general practitioner first suspects an elder to be vulnerable or obtains crucial information on } \\
\text { aggravation of (determinants of) vulnerability, THEN the physician should document an } \\
\text { estimation of health needs and demands, to be followed by an intervention plan to be coordinated } \\
\text { by a clearly identified professional. (NEW) }\end{array}$ \\
\hline 2 & $\begin{array}{l}\text { IF the general practitioner prescribes a vulnerable elder a new chronic disease medication, and } \\
\text { s/he has a follow-up visit with this physician, THEN } 1 \text { of the following should be noted at the } \\
\text { follow-up visit: } \\
\text { - Medication is being taken; } \\
\text { - } \quad \text { Patient was asked about the medication (e.g., side effects, adherence, availability); } \\
\text { - } \quad \text { Medication was not started because it was not needed or it was changed. }\end{array}$ \\
\hline 3 & $\begin{array}{l}\text { IF a vulnerable elder is under the outpatient care of } \geq 2 \text { physicians, and a physician other then the } \\
\text { GP prescribed a new chronic disease medication or a change in prescribed medication, THEN the } \\
\text { general practitioner should acknowledge the medication change at the next visit. }\end{array}$ \\
\hline 4 & $\begin{array}{l}\text { IF a vulnerable elder was referred to a medical specialist and after is seen again by the v, THEN } \\
\text { the general practitioners record should acknowledge the medical specialist's recommendations, } \\
\text { include the specialist's report, or indicate why the visit to the specialist did not occur. }\end{array}$ \\
\hline 5 & $\begin{array}{l}\text { IF a vulnerable elder was given an order for a diagnostic test by the general practitioner, THEN } 1 \\
\text { of the following should be documented at the follow-up visit: } \\
\text { - } \quad \text { Result of the test initialed/acknowledged; } \\
\text { - } \quad \text { Note that the test was not needed/reason why it will not be performed; } \\
\text { - } \quad \text { Note that the test is pending. }\end{array}$ \\
\hline 6 & $\begin{array}{l}\text { IF a vulnerable elder misses a needed preventive care event that is recurrent with a specific } \\
\text { periodicity (e.g. influenza vaccination or annual control of diabetics), THEN there should be } \\
\text { general practitioners record documentation of a reminder that the preventive care is needed within } \\
\text { one full interval since the missed event. }\end{array}$ \\
\hline 7 & $\begin{array}{l}\text { IF a vulnerable elder is discharged from a hospital to home and survives } \geq 4 \text { weeks after } \\
\text { discharge, THEN a general practitioner visit or telephone contact should be documented within } 6 \\
\text { weeks of discharge AND the general practitioners record should acknowledge the recent } \\
\text { hospitalization. }\end{array}$ \\
\hline 8 & $\begin{array}{l}\text { IF a vulnerable elder is discharged from a hospital to home and received a new chronic disease } \\
\text { medication or a change in medication prior to discharge, THEN the general practitioners record } \\
\text { should document the medication change at most } 3 \text { days after receiving the information from the } \\
\text { hospital. }\end{array}$ \\
\hline 9 & $\begin{array}{l}\text { IF a vulnerable elder is discharged from a hospital to home, THEN there should be a discharge } \\
\text { summary in the general practitioners record. }\end{array}$ \\
\hline 10 & $\begin{array}{l}\text { IF a vulnerable elder is discharged from a hospital to home and the discharge summary requests } \\
\text { the general practitioner to take certain actions, THEN the general practitioners record should } \\
\text { document the follow-up on the requested actions. }\end{array}$ \\
\hline 11 & $\begin{array}{l}\text { IF a vulnerable elder is discharged from a nursing home to home, THEN there should be a } \\
\text { discharge summary in general practitioners record. }\end{array}$ \\
\hline 12 & $\begin{array}{l}\text { IF a vulnerable elder is new to a general practitioners practice, THEN the general practitioners } \\
\text { record should contain general practitioners records from a prior care source, a request for such } \\
\text { general practitioners records, or an indication that such records are unavailable. }\end{array}$ \\
\hline \multirow[t]{2}{*}{13} & $\begin{array}{l}\text { IF a vulnerable elder is not able to understand the general practitioner due to language barriers or } \\
\text { deafness, THEN an interpreter (e.g. an informal caregiver) or translated materials should be } \\
\text { present to facilitate communication }\end{array}$ \\
\hline & DEMENTIA \\
\hline 1 & $\begin{array}{l}\text { IF a vulnerable elder new to a general practitioners practice presents with possible signs of } \\
\text { cognitive dysfunction and/or deficient mental or functional status, THEN there should be a } \\
\text { documented assessment of cognitive ability and functional status. }\end{array}$ \\
\hline 2 & ALL cognitive vulnerable elders should be evaluated at regular time intervals (the timing between \\
\hline
\end{tabular}




\begin{tabular}{|c|c|}
\hline & assessments depending on cognitive status) for changes in memory and functional status. \\
\hline 3 & $\begin{array}{l}\text { IF a vulnerable elder tests positive for dementia, THEN the general practitioner should review the } \\
\text { patient's medications (including over-the-counter) for any that may be associated with mental } \\
\text { status changes. }\end{array}$ \\
\hline 4 & $\begin{array}{l}\text { IF a vulnerable elder tests positive for dementia and is taking medications that are commonly } \\
\text { associated with mental status changes in the elderly, THEN the general practitioner should } \\
\text { discontinue or justify continuing these medications. }\end{array}$ \\
\hline 5 & $\begin{array}{l}\text { IF a vulnerable elder tests positive for dementia, THEN the general practitioner should document } \\
\text { an objective cognitive evaluation that assesses } \geq 2 \text { cognitive domains. }\end{array}$ \\
\hline 6 & $\begin{array}{l}\text { IF a vulnerable elder is newly diagnosed with dementia, THEN a general practitioner should } \\
\text { perform a neurologic examination that includes evaluation of gait, motor function, and reflexes. }\end{array}$ \\
\hline 7 & $\begin{array}{l}\text { IF a vulnerable elder is newly diagnosed with dementia, THEN Hb, Ht, MCV, BSE, glucose, } \\
\text { TSH and creatinine tests should be done and, if indicated, tests on electrolytes, folic acid, vitamin } \\
\text { B1, vitamin B6, vitamin B12, and liver function. }\end{array}$ \\
\hline 8 & $\begin{array}{l}\text { IF a vulnerable elder is diagnosed with dementia with recent onset symptoms (2-3 years), THEN } \\
\text { the general practitioner should refer the patient to a specialist if: } \\
\text { - The diagnosis of dementia cannot be made with certainty; } \\
\text { - The diagnosis of dementia is clear, but it has a) a conspicuous course; b) conspicuous } \\
\text { - } \quad \text { symptoms; c) indications of deviations which can be treated with specialist treatment. } \\
\text { - There is a need for the specialist's advice. }\end{array}$ \\
\hline 9 & $\begin{array}{l}\text { IF a vulnerable elder with dementia has a caregiver, THEN the general practitioner should give } \\
\text { the patient and/or caregiver information on the following: } \\
\text { - Dementia diagnosis, prognosis, and associated behavioral symptoms; } \\
\text { - Home occupational safety; } \\
\text { - } \quad \text { Suitability to drive a vehicle; } \\
\text { - } \quad \text { Possibility of medication with cholinesterase inhibitors or other agents that might affect } \\
\text { dementia symptoms or course without affording cure; } \\
\text { - Community resources; } \\
\text { - Care/ help for the informal caregiver. }\end{array}$ \\
\hline 10 & $\begin{array}{l}\text { IF a vulnerable elder has dementia, THEN s/he should be screened after at regular time-intervals } \\
\text { for psychotic affective disorders and/or behavioral problems (including BPSD). }\end{array}$ \\
\hline 11 & $\begin{array}{l}\text { IF a vulnerable elder with dementia is treated for psychotic affective disorder and/or behavioral } \\
\text { problems, THEN the general practitioners record should contain documentation that a psycho- } \\
\text { social intervention was tried first/concurrently, OR if treated first with a pharmacologic } \\
\text { intervention that the problem was severe. }\end{array}$ \\
\hline 12 & $\begin{array}{l}\text { IF a vulnerable elder with dementia and psychotic affective disorder and/or behavioral problems } \\
\text { is newly treated with an antipsychotic, THEN there should be a documented risk-benefit } \\
\text { discussion. }\end{array}$ \\
\hline \multirow[t]{2}{*}{13} & $\begin{array}{l}\text { IF an elder is vulnerable and the care-giver burden is high, THEN the general practitioner should } \\
\text { have a pro-active attitude towards cognitive dysfunction or dementia. (NEW) }\end{array}$ \\
\hline & DEPRESSION \\
\hline 1 & $\begin{array}{l}\text { IF a vulnerable elder receives a diagnosis of a new depression episode, THEN the general } \\
\text { practitioners record should document that the general practitioner has immediately provided } \\
\text { information on the target symptoms for depression. }\end{array}$ \\
\hline 2 & $\begin{array}{l}\text { IF a vulnerable elder receives a diagnosis of a new depression episode, THEN the general } \\
\text { practitioners record should document on the day of diagnosis: } \\
\text { - presence or absence of suicidal ideation; } \\
\text { - presence or absence of psychosis; } \\
\text { - presence or absence of past history of mania or hypomania; } \\
\text { - Presence or absence of anxiety. }\end{array}$ \\
\hline 3 & $\begin{array}{l}\text { IF a vulnerable elder receives a diagnosis of a new depression episode, THEN the general } \\
\text { practitioners record should document screening for the following co-morbid conditions } \\
\text { (documented within one month of the depression diagnosis or during the } 3 \text { months prior to } \\
\text { diagnosis): } \\
\text { - cardiovascular risk factors; } \\
\text { - hypothyroidism for women over age 50; }\end{array}$ \\
\hline
\end{tabular}




\begin{tabular}{|c|c|}
\hline & $\begin{array}{l}\text { - } \quad \text { substance dependence or abuse; } \\
\text { - } \quad \text { Parkinsonism; } \\
\text { - } \quad \text { Dementia. }\end{array}$ \\
\hline 4 & $\begin{array}{l}\text { IF a vulnerable elder has thoughts of suicide, THEN the medical record should document, on the } \\
\text { same date, that the patient either has no immediate plan for suicide, or that the patient was } \\
\text { referred for evaluation for psychiatric hospitalization. }\end{array}$ \\
\hline 5 & $\begin{array}{l}\text { IF a vulnerable elder is diagnosed with depression, THEN psychotherapy, or antidepressant } \\
\text { treatment, should be offered within } 2 \text { weeks after diagnosis unless there is documentation (e.g. } \\
\text { "watchful waiting") within that period that the patient has improved, or unless the patient has } \\
\text { substance abuse or dependence, in which case treatment may wait until six weeks after the patient } \\
\text { is in a drug or alcohol free state. }\end{array}$ \\
\hline 6 & $\begin{array}{l}\text { IF a vulnerable elder has depression with psychotic features, THEN he or she should be urgently } \\
\text { referred to a mental health specialist or emergency department specialized in mental health care. }\end{array}$ \\
\hline 7 & $\begin{array}{l}\text { IF a vulnerable elder has no meaningful symptom response after } 4-6 \text { weeks of treatment, THEN } \\
\text { the general practitioner should asses the reason for non-response, reconsider the diagnosis, check } \\
\text { compliance of the elder and eventually switch to another treatment. }\end{array}$ \\
\hline 8 & $\begin{array}{l}\text { IF a vulnerable elder has a diagnosis of depression for the first time and responds to the chosen } \\
\text { therapy, THEN he or she should be continued on the same treatment for at least } 6 \text { months during } \\
\text { which the general practitioner provides adequate monitoring. }\end{array}$ \\
\hline 9 & $\begin{array}{l}\text { IF a vulnerable elder has experienced three or more episodes of depression, THEN he or she } \\
\text { should receive continuing treatment for at least } 12 \text { months during which the general practitioner } \\
\text { provides adequate monitoring. }\end{array}$ \\
\hline \multirow[t]{2}{*}{10} & $\begin{array}{l}\text { IF a vulnerable elder has co morbid dementia or a somatic disease, THEN an existing depression } \\
\text { should still be treated. (NEW) }\end{array}$ \\
\hline & DIABETES \\
\hline 1 & $\begin{array}{l}\text { IF a vulnerable elder has diabetes, THEN glycated hemoglobin should be measured at least } \\
\text { annually. }\end{array}$ \\
\hline 2 & $\begin{array}{l}\text { IF a vulnerable elder has a fasting glucose level between } 4 \text { and } 7 \mathrm{mmol} / \mathrm{l} \text {, THEN the general } \\
\text { practitioner should initiate a therapeutic intervention within } 3 \text { months or should document why } \\
\text { this did not happen. }\end{array}$ \\
\hline 3 & $\begin{array}{l}\text { IF a diabetic vulnerable elder does not have established renal disease and is not receiving an ACE } \\
\text { inhibitor or ARB, THEN a test for creatinine clearance should be done annually. }\end{array}$ \\
\hline 4 & IF a vulnerable elder has diabetes, THEN a foot exam should be performed annually. \\
\hline 5 & $\begin{array}{l}\text { IF a diabetic, vulnerable elder is not blind, and did not have retinopathy on a previous } \\
\text { examination, THEN s/he should have a retinal eye examination or fundus photography performed } \\
\text { every } 2 \text { years. }\end{array}$ \\
\hline 6 & $\begin{array}{l}\text { IF a vulnerable elder has diabetes, THEN the general practitioner should measure the blood } \\
\text { pressure annually or for deviant values every } 3 \text { months. }\end{array}$ \\
\hline \multirow[t]{2}{*}{7} & $\begin{array}{l}\text { IF a diabetic vulnerable elder has a persistent (on } 2 \text { consecutive visits) elevation of systolic BP } \\
>140 \mathrm{~mm} \mathrm{Hg} \text {, THEN the general practitioner should initiate an intervention (pharmacologic, } \\
\text { lifestyle, compliance, etc.) or there should be documentation of a reversible cause/other } \\
\text { justification for the elevation or a reason why an intervention was not done. }\end{array}$ \\
\hline & END OF LIFE CARE \\
\hline 1 & $\begin{array}{l}\text { IF a vulnerable elder dies with a progressive incurable disease (for example metastatic cancer, or } \\
\text { dementia) THEN there should be evidence within } 6 \text { months prior to death that they received a } \\
\text { comprehensive assessment including: } \\
\text { - Pain; } \\
\text { - Anxiety, depression; } \\
\text { - Vomiting and dyspnea; } \\
\text { - Spiritual and existential concerns; } \\
\text { - Caregiver burdens/need for practical assistance; } \\
\text { - Wishes concerning medical treatment and care at the end of life; } \\
\text { - } \quad \text { A discussion about and if possible the determination of a surrogate decision maker. }\end{array}$ \\
\hline 2 & $\begin{array}{l}\text { IF a vulnerable elder with metastatic cancer or oxygen dependent pulmonary disease has dyspnea } \\
\text { refractory to non-opiate medications, THEN opiate medications should be offered. }\end{array}$ \\
\hline 3 & IF a vulnerable elder who had dyspnea in the last 7 days of life died an expected death, THEN \\
\hline
\end{tabular}




\begin{tabular}{|c|c|}
\hline & a snoula document a ayspea poncy (inciuaing inter \\
\hline 4 & $\begin{array}{l}\text { IF a vulnerable elder who was conscious during the last } 7 \text { days of life died an expected death, } \\
\text { THEN the general practitioners record should document a pain policy (including interventions). }\end{array}$ \\
\hline 5 & $\begin{array}{l}\text { IF a vulnerable elder is a caregiver for a spouse/significant other/dependent that is terminally ill } \\
\text { or has very limited function, THEN the vulnerable elder should be assessed for caregiver } \\
\text { financial, physical, and/or emotional stress. }\end{array}$ \\
\hline \multirow[t]{2}{*}{6} & $\begin{array}{l}\text { IF a vulnerable elder's spouse/significant other dies, THEN the vulnerable elder should be } \\
\text { assessed for depression or thoughts of suicidality within } 6 \text { months. }\end{array}$ \\
\hline & FALLS AND MOBILITY \\
\hline 1 & $\begin{array}{l}\text { IF a vulnerable elder reports a history of } \geq 2 \text { falls (or } 1 \text { fall for which the elder visits the general } \\
\text { practitioner) in the past year, THEN the general practitioner should document a basic fall history } \\
\text { (including type and circumstances of the falls, and possible contributing factors like medication, } \\
\text { chronic conditions, alcohol intake) within } 3 \text { months of the reported history (or within } 4 \text { weeks, if } \\
\text { the most recent fall occurred in the past } 4 \text { weeks). }\end{array}$ \\
\hline 2 & $\begin{array}{l}\text { IF a vulnerable elder reports a history of } \geq 2 \text { falls (or } 1 \text { fall for which the elder visits the general } \\
\text { practitioner) in the past year, THEN the general practitioner should document receipt of an eye } \\
\text { exam in the past year, or evidence of visual acuity testing within } 3 \text { months of the reported history. }\end{array}$ \\
\hline 3 & $\begin{array}{l}\text { IF a vulnerable elder reports a history of } \geq 2 \text { falls (or } 1 \text { fall for which the elder visits the general } \\
\text { practitioner) in the past year, or has worsening difficulty with ambulation, balance, or mobility, } \\
\text { THEN the general practitioner should document a basic gait, balance, and strength evaluation } \\
\text { within } 3 \text { months of the reported history (or within } 4 \text { weeks, if the most recent fall occurred in the } \\
\text { past } 4 \text { weeks). }\end{array}$ \\
\hline 4 & $\begin{array}{l}\text { IF a vulnerable elder reports a history of } \geq 2 \text { falls (or } 1 \text { fall for which the elder visits the general } \\
\text { practitioner) in the past year, THEN the general practitioner should document an assessment of } \\
\text { cognitive status in the past } 6 \text { months or within } 3 \text { months of the reported history (or within } 4 \\
\text { weeks, if the most recent fall occurred in the past } 4 \text { weeks). }\end{array}$ \\
\hline 5 & $\begin{array}{l}\text { IF a vulnerable elder reports a history of } \geq 2 \text { falls (or } 1 \text { fall for which the elder visits the general } \\
\text { practitioner) in the past year, THEN the general practitioner should document an assessment and } \\
\text { modification of home hazards recommended in the past year or within } 3 \text { months of the reported } \\
\text { history. }\end{array}$ \\
\hline 6 & $\begin{array}{l}\text { IF a vulnerable elder reports a history of } \geq 2 \text { falls (or } 1 \text { fall for which the elder visits the general } \\
\text { practitioner) in the past year and is taking a benzodiazepine, THEN the general practitioner } \\
\text { should document a discussion of related risks and assistance offered to reduce/discontinue } \\
\text { benzodiazepine use. }\end{array}$ \\
\hline 7 & $\begin{array}{l}\text { IF a vulnerable elder demonstrates decreased balance/proprioception or increased postural sway } \\
\text { AND does not have an assistive device, THEN an evaluation/prescription for an assistive device } \\
\text { should be offered within } 3 \text { months. }\end{array}$ \\
\hline 8 & $\begin{array}{l}\text { IF a vulnerable elder reports a history of } \geq 2 \text { falls (or } 1 \text { fall for which the elder visits the general } \\
\text { practitioner) in the past year AND has an assistive device, THEN there should be documentation } \\
\text { of an assistive device review in the past } 6 \text { months or within } 3 \text { months of the reported history (or } \\
\text { within } 4 \text { weeks, if the most recent fall occurred in the past } 4 \text { weeks). }\end{array}$ \\
\hline \multirow[t]{2}{*}{9} & $\begin{array}{l}\text { IF a vulnerable elder is found to have a problem with gait, balance, strength, or endurance, } \\
\text { THEN there should be documentation of a structured/supervised exercise program offered in the } \\
\text { past } 6 \text { months or within } 3 \text { months of noting the problem. }\end{array}$ \\
\hline & MEDICATION USE \\
\hline 1 & $\begin{array}{l}\text { IF a vulnerable elder is prescribed a drug, THEN the prescribed drug should have a clearly } \\
\text { defined indication. }\end{array}$ \\
\hline 2 & $\begin{array}{l}\text { IF a vulnerable elder is prescribed a drug, THEN the vulnerable elder (or a caregiver) should } \\
\text { receive appropriate education about its use. }\end{array}$ \\
\hline 3 & $\begin{array}{l}\text { ALL vulnerable elders should have an up-to-date medication list readily available in the general } \\
\text { practitioners record, accessible by all healthcare providers, and including, if known, over-the- } \\
\text { counter medications. }\end{array}$ \\
\hline 4 & $\begin{array}{l}\text { IF a vulnerable elder is prescribed an ongoing medication for a chronic medical condition, THEN } \\
\text { there should be a documentation of response to therapy. }\end{array}$ \\
\hline 5 & ALL vulnerable elders should have an annual drug regimen review. \\
\hline 6 & $\begin{array}{l}\text { IF a vulnerable elder is prescribed an oral anticoagulant by the Dutch Thrombosis Service or } \\
\text { otherwise, THEN this should be clearly marked in the general practitioners record. }\end{array}$ \\
\hline 7 & IF a vulnerable elder is prescribed an ACE inhibitor, THEN s/he should have serum creatinine \\
\hline
\end{tabular}




\begin{tabular}{|c|c|}
\hline & and potassium monitored within 2 weeks after initiation of therapy and at least yearly thereafter. \\
\hline 8 & $\begin{array}{l}\text { IF a vulnerable elder is prescribed a loop diuretic, THEN s/he should have electrolytes checked } \\
\text { within } 2 \text { weeks after initiation and at least yearly thereafter. }\end{array}$ \\
\hline 9 & $\begin{array}{l}\text { IF a vulnerable elder is taking a benzodiazepine ( }>2 \text { weeks), THEN the general practitioner } \\
\text { should stop or taper this treatment, unless documented discussion with the patient provides } \\
\text { counterarguments. }\end{array}$ \\
\hline 10 & $\begin{array}{l}\text { ALL vulnerable elders should not be prescribed any medication with strong anticholinergic } \\
\text { effects if alternatives are available. }\end{array}$ \\
\hline 11 & $\begin{array}{l}\text { IF a vulnerable elder is started on an antipsychotic drug, THEN the general practitioner should } \\
\text { document a first assessment of response within } 1 \text { week. }\end{array}$ \\
\hline 12 & $\begin{array}{l}\text { IF a vulnerable elder is prescribed a NSAID (non-selective or selective), THEN the general } \\
\text { practitioner should document a discussion or consideration of gastrointestinal bleeding risks. }\end{array}$ \\
\hline 13 & $\begin{array}{l}\text { IF a vulnerable elder is prescribed low-dose }(\leq 325 \mathrm{mg} / \mathrm{day}) \text { aspirin, THEN the general } \\
\text { practitioner should consider the associated gastrointestinal bleeding risks and advise the } \\
\text { vulnerable elder accordingly. }\end{array}$ \\
\hline 14 & $\begin{array}{l}\text { IF a vulnerable elder is prescribed chronic high-dose acetaminophen ( } \geq 3 \text { grams/day) OR a } \\
\text { vulnerable elder with liver disease is prescribed chronic acetaminophen THEN s/he should be } \\
\text { advised of the risk of liver toxicity }\end{array}$ \\
\hline 15 & $\begin{array}{l}\text { IF a vulnerable elder is prescribed an NSAID, THEN the GP record should indicate whether or } \\
\text { not s/he has a history of 1) gastrointestinal bleeding or ulcers and 2) renal insufficiency or } 3 \text { ) heart } \\
\text { failure AND, if a history is present, the general practitioner should document justification of } \\
\text { NSAID use. }\end{array}$ \\
\hline 16 & $\begin{array}{l}\text { IF a vulnerable elder is treated with a NSAID, THEN s/he should be treated concomitantly with } \\
\text { either misoprostol or a proton pump inhibitor. }\end{array}$ \\
\hline \multirow[t]{2}{*}{17} & $\begin{array}{l}\text { IF a vulnerable elder is treated with daily NSAIDs (selective or nonselective) AND the vulnerable } \\
\text { elder has risk factors for developing renal insufficiency, THEN serum creatinine should be } \\
\text { assessed at baseline and at least once in the first year following the initiation of therapy. }\end{array}$ \\
\hline & UNDERNUTRITION \\
\hline 1 & $\begin{array}{l}\text { ALL vulnerable elders in stable health states should take } 800 \text { IU (or equivalent) of vitamin D } \\
\text { supplementation daily. }\end{array}$ \\
\hline 2 & $\begin{array}{l}\text { IF a vulnerable elder has involuntary weight loss of } \geq 10 \% \text { of body weight in } \leq 1 \text { year, THEN the } \\
\text { general practitioner should document weight loss (or a related disorder) as recognition of } \\
\text { undernutrition as a potential problem. }\end{array}$ \\
\hline 3 & $\begin{array}{l}\text { IF a vulnerable elder has involuntary weight loss of } \geq 10 \% \text { in } \leq 1 \text { year or hypoalbuminemia }(<3.5 \\
\text { g/dl), THEN s/he should be evaluated for potentially reversible causes of poor nutritional intake } \\
\text { including assessment of: } \\
\text { - } \quad \text { Dental status (e.g., reference to dentition, gum health, dental referral); } \\
\text { - } \quad \text { Food security (e.g., financial status, social work referral); } \\
\text { - } \quad \text { Food-related functional status (e.g., ability to feed, prepare meals); } \\
\text { - } \quad \text { Appetite and intake (e.g., } 72 \text {-hour calorie count, dietitian referral); } \\
\text { - } \quad \text { Swallowing ability (e.g., bedside swallowing study, swallowing study referral); } \\
\text { - } \quad \text { Dietary restrictions (e.g., low salt or low protein diet). }\end{array}$ \\
\hline 4 & $\begin{array}{l}\text { IF a vulnerable elders has involuntary weight loss of } \geq 10 \% \text { in } \leq 1 \text { year or hypoalbuminemia }(<3.5 \\
\text { g/dl), THEN s/he should be evaluated for potentially relevant comorbid conditions, including } \\
\text { assessment of: } \\
\text { - } \quad \text { Medications associated with decreased appetite (e.g., digoxin, SSRIs, amphetamines); } \\
\text { - } \quad \text { Depression; } \\
\text { - Cognitive impairment; } \\
\text { - Thyroid function; } \\
\text { - } \quad \text { Cancer, diabetes, malabsorption (e.g., exam of lymph nodes, breast, abdomen, prostate; CBC, } \\
\text { erythrocyte sedimentation rate, and comprehensive metabolic panel). }\end{array}$ \\
\hline 5 & $\begin{array}{l}\text { IF a vulnerable elder has an advanced stage of COPD, THEN the general practitioner should } \\
\text { monitor the elder's body weight and recommend energy-enriched food. (NEW) }\end{array}$ \\
\hline 6 & $\begin{array}{l}\text { IF a vulnerable elder is at risk of, or suffering from, decubitus, THEN the general practitioner } \\
\text { should consult a dietician. (NEW) }\end{array}$ \\
\hline
\end{tabular}

